\title{
Knowledge sharing practices in informal scholarly communication amongst academics in Poland
}

\author{
Marzena Świgoń \\ Department of Archive, Library and Information Science, \\ University of Warmia and Mazury in Olsztyn, \\ 10-725 Olsztyn, ul. Kurta Obitza 1, POLAND \\ e-mail: marzena.swigon@uwm.edu.pl
}

\begin{abstract}
This study explored knowledge sharing practices in Polish informal scholarly communication. The informal channels of communication include discussion, conversation, information exchange in both forms: face to face and via information and communication technologies. The study was carried out among the Polish academic community using a structured online questionnaire, which contained 88 questions (closed and partly open). Respondents consisted of academics: PhD, PhD with Habilitation, and Professors, employed in several types of universities and academia located throughout the country. A total of 1558 academics responded to the survey, representing all academic disciplines humanities, social sciences, technical and life sciences. The Polish academic community created rather homogenous networks, generally limited to their own disciplines. The favourite platform to share knowledge was unofficial talks during conferences and seminars. The preferable form of knowledge sharing practices was face to face talks, despite the development of modern information and communication technologies. The biggest barrier to knowledge sharing was the lack of time for free conversations. The most important motivator could be the interest of colleagues. Polish researchers commonly used only electronic mail and rarely used social media and blogs to share knowledge. This is the first national survey about knowledge sharing practices in Polish academic environment.
\end{abstract}

Keywords: Academics; Knowledge sharing; Information exchange; Scholarly communication; Informal channels of communication.

\section{INTRODUCTION}

The term knowledge sharing in an academic context can have different meanings. For example, it may be related to the transfer of scientific knowledge to industry and business world, to the dissemination of research results amongst citizens or to information exchange via communication technologies. However, in this paper knowledge sharing, which encompasses information sharing, is understood as a kind of informal scholarly communication between academics (Świgoń 2015a). Researchers share knowledge in the scholarly communication processes: formal and informal. Informal communication relates to conversation and discussion, which are the fundamental forms of scientific progress, practised by philosophers like Plato as well as contemporary researchers. The academic article, as the oldest form of so called formal knowledge sharing channels, appeared only in the 17th century. These formal channels include monographs, conference proceedings and contemporary various electronic and digital publications. 
Nevertheless, conversation remains the basic way of knowledge sharing. Today's scientists, researchers and academics share their knowledge constantly, face to face and via the information and communication technologies. Formal channels of scholarly communication are easy to observe and even measure. We can count numbers of publications, summarise scientific impact, watch citations and observe scientific networks all over the world. However, informal scholarly communication plays a crucial role in creation of new knowledge and information, because it creates greater connections and promotes scientific progress more effectively than the formal scholarly communication (de Solla Price 1967; Pikas 2006). The overriding concept for knowledge (and information) sharing is knowledge (and information) management. In other words, knowledge and information sharing is one of the main components of the knowledge and information value chain, along with knowledge (and information, skills, expertise) acquiring as well as new knowledge creation (Świgon 2012; 2013). Some authors state that knowledge sharing is the crucial point of the entire process of knowledge management (Jashapara 2005; Nonaka and Takeuchi 1995).

In the context of this study, knowledge sharing may be defined as an activity through which knowledge (namely information, skills, expertise) is exchanged among the academic communities. It is worth adding relations between basic terms: knowledge and information have been described by many authors, but the origin of this issue stem from classic literature of information science, e.g. from Bertram Brookes or John Farradane. Brookes (1980) regarded knowledge as a structure of concepts linked by their relations and information as a small part of such a structure. His fundamental equation (1) stated that the knowledge structure $K[S]$ is changed to the new modified structure $K[S+\Delta S$ ] by the information $\Delta I$, the $\Delta S$ indicating the effect of this modification.

$$
\mathrm{K}[\mathrm{S}]+\Delta \mathrm{I}=\mathrm{K}[\mathrm{S}+\Delta \mathrm{S}]
$$

Although information in this equation is a part of knowledge, it is important to highlight that differences between these terms are intuitively understood. In a communication context, formal and informal, information is a physical surrogate of knowledge (Farradane 1980). From all types of knowledge: tacit, implicit and explicit (Bennet and Bennet 2008; Day 2005; Nonaka and Takeuchi 1995; Polanyi 1958), its explicit form is the closest to the notion of information (Al-Hawamdeh 2002; Bates 2005; Nonaka and Takeuchi 1995). Nevertheless, all of them can be communicated in an informal communication, e.g. during face to face conversation. It is important to add that tacit knowledge and implicit knowledge (e.g. skills) are not easy to articulate. They can transfer via internalization and socialization (Nonaka and Takeuchi 1995).

Knowledge sharing, as well as knowledge management - the overriding phenomenon, can be analysed at various levels or perspectives: individual, group, organisation and social (Świgon 2012). The effect of discussion or conversation is influenced by the variety of variables connected with all these perspectives. These variables may be categorised into three groups: personal characteristics, environmental and organisational, and technological (Świgon 2015a; 2015b). In other words, when people talk to each other, as in informal scholarly communication, not only personal characteristics are significant. Environmental variables (e.g. place, occasion), organisation (e.g. discipline, institute) and technology are crucial as well. Various variables and issues relate to knowledge and information sharing. These variables, that is personal, organisational and technological, can enhance or hinder the process of sharing knowledge (and information, skills, expertise). We can talk about motivators and barriers in knowledge sharing. Moreover, the entire process relates to all abovementioned forms of knowledge: tacit, implicit and explicit. The simplified model of 
intervening variables and issues in knowledge (and information, skills, expertise) sharing in various contexts, not only academic, is presented in Figure 1. The knowledge sharing phenomenon is complex in nature, but is very interesting and important for future development in all fields. The academic environment particularly is the focus of the study because here the new knowledge is created.

The intervening variables and issues, presented in Figure 1, were used in the current study. All questions and statements in the questionnaire were formulated based on this model. Moreover, respondents described some of the intervening variables and issues in their answers.

Figure 1: Intervening Variables and Issues in Knowledge Sharing.

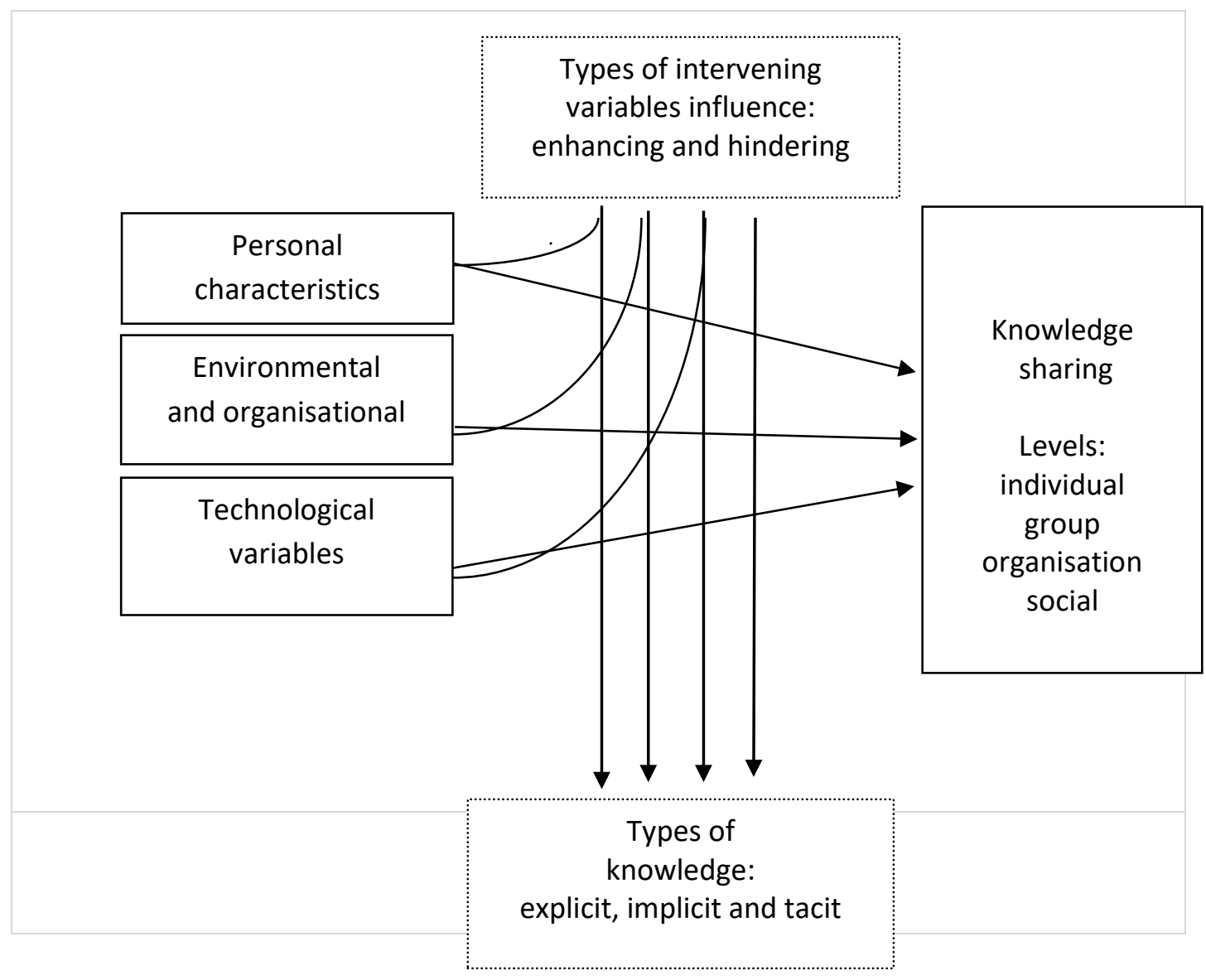

\section{LITERATURE REVIEW}

The purpose of this paper is to describe knowledge sharing practices amongst Polish academics. This has been studied at the international level (Tenopir et al. 2016) and the national issue (the broadest perspective) has been presented in analyses from United Kingdom (Fullwood, Rowley and Delbridge 2013), Iran (Dokhtesmati and Bousari 2013), South Korea (Kim and Ju 2008), Malaysia (Abrizah, Hilmi and Norliya 2015; Abrizah et al. 2015; Cheng, Ho and Lau 2009; Chong, Yuen and Gan 2014; Nordin, Daud and Osman 2012; Ramayah, Yeap and Ignatius 2013; Sohail and Daud 2009), Denmark (Lauring and Selmer 2012), Spain (Padilla-Meléndez and Garrido-Moreno 2012; Fernándes-Pérez et al. 2014), and Sweden (Pilerot and Limberg 2011; Pilerot 2013), but not from Poland. Moreover, there is a 
strong body of research into knowledge sharing in commercial environments, whereas such research in universities is limited (Fullwood, Rowley and Delbridge 2013). Existing publications are rather general in nature (Cheng Ho and Lau 2009; Chong, Yuen and Gan 2014; Dokhtesmati and Bousari 2013; Fullwood, Rowley and Delbridge 2013; Nordin, Daud and Osman 2012; Padilla-Meléndez and Garrido-Moreno 2012; Ramayah, Yeap and Ignatius 2013; Sohail and Daud 2009). Among them there are studies connected with one discipline (Hass and Park 2010). Sometimes research focuses on detailed issues e.g. individuals' personality in this context (Wang and Yang 2007), business networks of academics (Fernándes-Pérez et al. 2014) or knowledge sharing through institutional repositories on campus (Kim and Ju 2008). Recently the role of technological channels of communication has been analysed, e.g. blogs, wikis, Open Access, Facebook, Twitter (Forkosh-Baruch and Hershkovitz 2012; Luzón 2009; Xiao and Askin 2014).

In the light of study in several UK universities, academics had a low level of affiliation to their academia, but prominent level of affiliation to their discipline and high level of autonomy. In general, they had positive attitudes and intentions towards knowledge sharing. They believed that knowledge sharing can improve their professional relationships and offer opportunities for internal promotion and external appointments (Fullwood et al. 2013). In Iranian academic institutions, the organizational culture did not support knowledge sharing. The important barriers were for example: lack of trust, lack of time, lack of team work (Dokhtesmati and Bousari 2013). The perception of knowledge sharing and the appropriate reward system were the influential factors for faculty knowledge sharing in South Korean academia (Kim and Ju 2008). The staff of private universities in Malaysia were more effective in knowledge sharing than those of public academia. A significant relationship between knowledge sharing in public academia and such factors as working culture, staff attitude, motivation and opportunities to share knowledge were observed. Moreover, the Malaysian study revealed that reciprocal relationships, sense of self-worth and subjective norm influenced staff attitudes towards knowledge sharing (Chong, Yuen and Gan 2014; Ramayah, Yeap and Ignatius 2013; Sohail and Daud, 2009). In the light of the Danish study, knowledge sharing had more positive associations with diversity related to cultural and linguistic internationalization, than demographic, such as age or gender (Lauring and Selmer 2012). According to Spanish studies, factors such as personal and professional profile, institutional variables and social networks had a very positive influence on knowledge sharing. Furthermore, business networks of academics played a crucial role in their entrepreneurial intentions and engagement in commercially oriented fields of research (Padilla-Meléndez and Garrido-Moreno 2012; Fernándes-Pérez et al. 2014). Swedish studies revealed that there is a reciprocal relationship between information and communication technologies and the ways in which information is used and shared. Moreover, trust, people, tools and places play significant role in information sharing amongst academics (Pilerot and Limberg 2011; Pilerot 2013).

This paper and the monograph in Polish (Świgon 2015a) is not only an up to date study on the knowledge and information sharing in Polish academic environment, but also is the first national survey. It focused on knowledge sharing through face to face communication as well as information and communication technologies. Representatives of all disciplines employed in a variety of types of academia were taken into consideration. In this national survey different perspectives of individual, group, and organisation are presented. 


\section{OBJECTIVE AND RESEARCH QUESTIONS}

The purpose of the research was to explore the phenomenon of knowledge sharing amongst Polish academics. Knowledge sharing is defined as an activity which knowledge (covering information, skills, expertise) is exchanged among the academic communities. Knowledge sharing is understood in this research as a kind of informal scholarly communication, which can occur through face to face conversations or via information-communication technologies. The following research questions were posed:

a) How does the Polish academic community perceive knowledge sharing?

b) What are the attitudes and intentions of Polish academics towards sharing knowledge in an informal scholarly communication processes?

c) Which are the most popular occasions (e.g. opportunities, technologies and tools) to share knowledge in an academic context?

d) What are the enhancing and hindering variables (motivators and barriers) influencing the sharing of knowledge in the Polish academic community?

In addition to the abovementioned research questions, the following hypotheses was developed: "there is no significant difference between subgroups of respondents (gender, age, academic position) as to their perception of various knowledge sharing issues".

\section{METHOD}

The national survey was conducted in the academic year 2013/2014, two years after the reform of the Polish higher education system (Reforms... 2011). The respondents group stem from the Polish Science - Scientists database, created by the National Information Processing Institute (http://www.opi.org.pl/en/home.html). The Scientists database includes information about Polish citizens with a PhD degree or higher (Habilitation, which is a specific step in a Polish scientific career, or Professor, the highest level). Over 40 thousand inquiries with the link to an anonymous questionnaire were sent to registered academics, employed in universities and other types of academia in Poland. Over one and a half thousand answers were received (return rate 3.6\%), and 1558 were suitable for this analysis. According to the Central Statistical Office of Poland, respondents constituted 2.3 percent of the general number of academics (66391) employed in Polish academia in 2013/2014. Surveyed academics were employed in various establishments, state and private, located throughout the whole country. They represented various kinds of academic disciplines (List...2006). Details of the respondent group (gender, age, academic position, disciplines and type of academia) are presented in Table 1.

The questionnaire contained 88 questions, closed and partly open. Respondents selected an answer from two sets of a five-point Likert scale (1, strongly disagree; 2, disagree; 3 , undecided; 4, agree; 5 , strongly agree or 1 , not at all; 2 , rarely; 3 , sometimes; 4, often; 5 , constantly). The statistical methods were used to analyse gathered data (using Statistica PL). In the analysis of data gathered in this study, some statistical methods: test $t$ and analysis of variance (ANOVA) were used. The hypotheses were tested at 0.05 level of significance. 
Świgoń, $M$.

Table 1: The Respondents Grouped by Gender, Academic Status, Age, Academic Disciplines, and Type of Academia

\begin{tabular}{|c|c|c|}
\hline Gender & Frequency & Percent \\
\hline Women & 675 & 43.3 \\
\hline Men & 883 & 56.7 \\
\hline Total & 1558 & 100 \\
\hline Academic position & Frequency & Percent \\
\hline Doctor (PhD) & 928 & 59.6 \\
\hline Doctor with Habilitation (PhD with Habilitation) & 411 & 26.4 \\
\hline Professor & 219 & 14.1 \\
\hline Total & 1558 & 100 \\
\hline Age & Frequency & Percent \\
\hline Until 39 years old & 482 & 30.9 \\
\hline $40-55$ years old & 691 & 44.3 \\
\hline 56 years and more & 385 & 24.8 \\
\hline Total & 1558 & 100 \\
\hline Academic disciplines & Frequency & Percent \\
\hline Humanities & 329 & 21.1 \\
\hline Theology & 20 & 1.3 \\
\hline Social studies & 112 & 7.2 \\
\hline Economics & 187 & 12.0 \\
\hline Law & 43 & 2.7 \\
\hline Mathematics & 41 & 2.6 \\
\hline Physical sciences & 59 & 3.8 \\
\hline Chemical sciences & 94 & 6.0 \\
\hline Biological sciences & 90 & 5.7 \\
\hline Earth sciences & 61 & 3.9 \\
\hline Technology & 271 & 17.4 \\
\hline Agricultural sciences & 83 & 5.3 \\
\hline Forestry science & 10 & 0.7 \\
\hline Veterinary science & 11 & 0.7 \\
\hline Medical science & 79 & 5.1 \\
\hline Pharmaceutical science & 20 & 1.3 \\
\hline Health science & 14 & 0.9 \\
\hline Sport science & 17 & 1.1 \\
\hline Film studies & 3 & 0.2 \\
\hline Music studies & 3 & 0.2 \\
\hline Fine art & 10 & 0.7 \\
\hline Drama and theatre studies & 1 & 0.1 \\
\hline Total & 1558 & 100 \\
\hline Academia & Frequency & Percent \\
\hline University & 784 & 50.3 \\
\hline Technical university & 344 & 22.0 \\
\hline Others (agricultural, medical, pedagogic, economic etc.) & 430 & 27.7 \\
\hline Total & 1558 & 100 \\
\hline
\end{tabular}




\section{FINDINGS}

The findings of this study are presented based on the research questions, highlighting the fundamental issues contained in the questionnaire.

\section{Perceptions of Knowledge Sharing}

One of the basic issues explored in the survey was the perceptions of the Polish academics on knowledge sharing. Five statements reflecting perception of knowledge sharing (Table 2) were offered in the questionnaire. Two of these statements received a high agreement level from the respondents: Sharing scientific knowledge is occasion to broaden knowledge and Sharing scientific knowledge is pleasure. Other statements were much less agreeable amongst the Polish academics.

Table 2: Perceptions of Knowledge Sharing

\begin{tabular}{l|r}
\hline \hline Sharing scientific knowledge is & Mean \\
\hline \hline Occasion to broaden knowledge & 4.48 \\
\hline \hline Pleasure & 4.30 \\
\hline \hline Enhancement of professional position & 3.52 \\
\hline \hline Element of professional image creation & 3.39 \\
\hline \hline Necessity connected with the job & 3.31 \\
\hline \hline
\end{tabular}

The influence of all analysed variables (gender, status, discipline, age) on the answers of respondents was observed $(p<0.001)$. The biggest influence was the age variable. The average agreements with statements about perception of knowledge sharing as necessity connected with the job, as well as pleasure, were higher among the older respondents $(\mathrm{F}=18.92, \mathrm{~F}=11.32$ respectively). Whereas the average agreements with perception of knowledge sharing as an occasion to broaden knowledge, image creation and enhancement of professional position, decreased amongst older academics ( $F=3.58, F=13.87, F=4.65)$. An analogical observation related to the academic position - i.e. the higher the academic position, the higher agreement with both statements - on pleasure $(F=18.41)$ and necessity connected with the job $(F=22.13)$. The opposite was found with the statement on image creation - the higher the academic position, the lower the agreement with this statement $(F=13.14)$. The highest agreement with perception of knowledge sharing as a pleasure was observed amongst physicists and representatives of health science, as well as fine art $(F=1.94 \wedge p=0.006)$. Women, in comparison to men, were more convinced that knowledge sharing is an occasion to broaden knowledge $(F=27.67)$ and an effective way of enhancing professional position ( $\mathrm{F}=13.3$ ).

\section{Intentions to Share Knowledge}

There are several reasons why Polish academics initiate scientific conversations and the main intention is to broaden personal scientific networks. Five statements (Table 3 ) were identified in the questionnaire. Two reasons that received a high agreement level from the respondents are: Searching for detailed information about certain research problem and Exchange of opinion about current development in research discipline, study results, methodology.

From three analysed variables, only gender had important $(p<0.001)$ influence on these answers. Women selected higher scores of agreements than men, regarding almost all answers, except for "willingness to disseminate information about their own publications" (respectively: $F=27.45, F=20.86, F=14.49, F=23.49$ ). 
Table 3: Reasons to Initiate Scientific Conversations

\begin{tabular}{l||r}
\hline \hline Reasons for Initiation of Scientific Conversations & Mean \\
\hline \hline Searching for detailed information about certain research problem & 4.22 \\
\hline \hline $\begin{array}{l}\text { Exchange of opinion about current development in research discipline, study } \\
\text { results, methodology. }\end{array}$ & 4.15 \\
\hline \hline Desire to meet a person whose publications are valuable & 3.85 \\
\hline \hline Searching for partners for collaboration & 3.72 \\
\hline \hline Willingness to disseminate information about their own publications & 3.65 \\
\hline \hline
\end{tabular}

Regarding with whom Polish academics intend to broaden their professional networks with, six categories of subjects were identified in the questionnaire. The following subject hierarchy was obtained (Table 4): (a) representatives of own discipline abroad; (b) representatives of own discipline in Poland; (c) representatives of different disciplines; (d) home faculty; (e) mainly close colleagues; (f) mainly people who initiate relations. This shows that Polish academics mostly agree to broaden their scientific networks with international academics from their own discipline. Relations with representatives of the same institution were not considered of great value. On the other hand, the surveyed Polish community was opposed to closed personal networks (low level of respondents' agreement with last two statements).

Table 4: The Intentions to Share Knowledge with Scientific Networks

\begin{tabular}{l|r}
\hline \hline Intentions to broaden scientific network amongst & Mean \\
\hline \hline Representatives of own discipline abroad & 4.12 \\
\hline \hline Representatives of own discipline in Poland & 4.01 \\
\hline \hline Representatives of different disciplines & 4.01 \\
\hline \hline Home faculty & 3.44 \\
\hline \hline Mainly close colleagues & 3.06 \\
\hline \hline
\end{tabular}

This study considers the first four intentions as proactive in a knowledge sharing context, while the last two are passive knowledge sharing. The study showed that gender variable had varied the respondents' answers to the greatest extent. The results illustrated that women perceived $(p<0,001)$ proactive attitudes in broadening personal networks as more serious issues than men (respectively: $F=21.74, F=24.73, F=10.97, F=4.15^{\wedge} p=0.041$ ). The men, more than women, agreed with passive attitudes $(F=19.69, F=27.55)$. On the account of respondents' age and academic position, one could observe the following linear relation: the older age and advanced academic position of the academics, the higher their agreement with the passive statements, and the lower their agreement with three proactive attitudes (respectively - age: $\mathrm{F}=53.42, \mathrm{~F}=17.58, \mathrm{~F}=14.38, \mathrm{~F}=38.02, \mathrm{~F}=38.04$; and academic position: $F=20.08, F=18.62, F=8.55, F=21.19, F=11.5$ ).

\section{Opportunities to Share Knowledge}

Another issue raised in this study was the opportunities (popular occasions) to share knowledge in an academic environment and the preferred forms of these relationships. The respondents agreed that the most important opportunity to share knowledge is through unofficial talks during conferences and seminars, for example during breaks at these gatherings, followed by post doc stays and visits in other centres, and meetings initiated by researchers (Table 5). A disturbing observation in these results was the lowest assessment of meetings organised by managers of home institutes or departments. Perhaps such meetings 
are only a good opportunity for organisational issues, and not of great value for scientific and substantive discussion.

The study showed that the gender variable had varied the respondents' answers to the greatest extent. The women perceived these four opportunities more importantly than the men did: talks during conferences $\left(F=6.65^{\wedge} p=0.009\right)$, stays and visits $\left(F=12.87^{\wedge} p<0.001\right)$, meetings organised by scientific societies $\left(F=38.61^{\wedge} p<0.001\right)$, and meetings in home institutes $\left(F=4.8^{\wedge} p=0.028\right)$.

Table 5: Opportunities to Share Knowledge

\begin{tabular}{l|r}
\hline \hline Opportunities & Mean \\
\hline \hline Unofficial talks during conferences and seminars & 4.25 \\
\hline \hline Post doc stays and visits in other centres & 3.91 \\
\hline \hline Meetings initiated by researchers & 3.89 \\
\hline \hline External meetings with other cooperative organisation & 3.58 \\
\hline \hline Meetings organised by scientific societies & 3.54 \\
\hline \hline Possibilities connected with the Internet & 3.51 \\
\hline \hline Meetings in home institution, organised by managers & 3.22 \\
\hline \hline
\end{tabular}

The study identified four forms of relations in knowledge sharing preferred by the respondents, and the following order was obtained (Table 6): (a) face to face talks (of two or more people); (b) face to face discussions (groups of around a dozen); (c) relations via communication technologies (e-mail, chats etc.); (d) participation in group discussions on internet forums and platforms (with many people without knowing them). As foreseen, no form of contact was better than face to face communication. Innovative technologies are very helpful in global communication, but cannot alternate scientific dialogs.

Table 6: Forms of Relations in Knowledge Sharing

\begin{tabular}{l|r}
\hline \hline Forms of Relations & Mean \\
\hline \hline Face to face talks (of two or more people) & 4.50 \\
\hline \hline Face to face discussions (groups of around a dozen) & 3.64 \\
\hline \hline Relations via communication technologies (e-mail, chats etc.) & 3.63 \\
\hline $\begin{array}{l}\text { Participation in group discussions on internet forums and } \\
\text { platforms (with many people without knowing them) }\end{array}$ & 2.36 \\
\hline \hline
\end{tabular}

The little differences in subgroups of respondents were pointed out in this finding of the study. The most important differences were connected with variables of age and academic position, and respondents' perception of internet forums. There were linear relations: the higher the age and the academic position, the lower the assessment of usability of knowledge sharing via internet forums (respectively - age: $F=6.29, F=8.62, p=0.001$; status: $\mathrm{F}=8.62, \mathrm{p}<0.001)$.

\section{Perception of Peer Academics' Attitudes Towards Knowledge Sharing}

One of the intent of this study was to explore Polish academics' opinions about their colleagues in the context of knowledge sharing practices. The following descriptions were obtained in rank order: (a) inspirational; (b) open and talkative; (c) authority and father figure; (d) initiators of scientific discussions; and (e) oriented toward team work. In general, respondents' assessments of their peer academics were "average" or rather undecided, 
none of the abovementioned names exceeded 4 points of agreement in the 5-point scale (Table 7).

Table 7: Perception of Peer Academics in the Context of Knowledge Sharing

\begin{tabular}{l|r}
\hline \hline Peer academics are & Mean \\
\hline \hline Inspirational & 3.64 \\
\hline \hline Open and talkative & 3.58 \\
\hline \hline Authority, father figure & 3.49 \\
\hline \hline Initiators of scientific discussions & 3.16 \\
\hline \hline Oriented toward team work & 3.09 \\
\hline \hline
\end{tabular}

The study showed that the academic position variable had varied the academics' answers to the greatest extent. The results illustrated a linear relation connected with four descriptions (except the first i.e. inspirational) - the higher the academic position of the respondents, the higher their assessments of colleagues' attitudes (respectively: $F=4.17, p=0.015 ; F=9.63$, $p<0.001 ; F=8.18, p<0.001 ; F=5.23, p=0.005)$.

\section{Motivations of Knowledge Sharing}

About motivations of sharing knowledge (the enhancing variables) amongst Polish academics, the potential options are listed in Table 8 in rank order. Other scientists showing interest in one's knowledge and opinion is the only motivator considered of significant importance in stimulating knowledge sharing in the Polish academic environment. In other words, the biggest incentive to obtain scientific knowledge from researchers is an interest in colleagues' knowledge and opinion. An interesting finding from this part of studies is the lesser importance of such motivations as encouragement from management as well as monetary rewards.

Table 8: Motivators to Knowledge Sharing

\begin{tabular}{l|r}
\hline \hline Motivators & Mean \\
\hline \hline Other scientists showing interest in one's knowledge and opinion & 4.08 \\
\hline \hline Reciprocal exchange of knowledge and information & 3.78 \\
\hline \hline Good reputation in the eyes of other people & 3.59 \\
\hline \hline Additional points in faculty evaluation or other nonfinancial forms of recognition & 3.51 \\
\hline \hline Financial incentives or remuneration systems promoting knowledge sharing & 3.14 \\
\hline \hline
\end{tabular}

The following linear relation was observed regarding respondents' academic position $(p<0.001)$ : the higher the academic position, the lower the acknowledgement of perceived motivators (except for the first statement, respectively: $F=19.73, F=16.63, F=26.06, F=20.93$, $F=43.23)$. Besides, the gender variable varied the academics answers $(p<0.001)$ : the women perceived various motivators and stimuli (except of monetary rewards) as much more encouraging than the men $\operatorname{did}(\mathrm{F}=11.46, \mathrm{~F}=9.33, \mathrm{~F}=12.75, \mathrm{~F}=16.19, \mathrm{~F}=39.38)$.

\section{Barriers to Knowledge Sharing}

The study also identified the obstacles encountered by Polish academics during knowledge sharing in the Polish scientific environment. Nine possible obstacles are listed in Table 9 in rank order. In the light of the respondents' answers, all specified barriers in a knowledge sharing context had little importance. Other than the first three barriers (lack of time, lack 
of remuneration system and absence of specialists and expertise) the rest received a disagreement among the Polish academics as barriers to knowledge sharing.

Two variables: age and academic position varied the respondents' answers to the greatest extent $(p<0.001)$. The older the age of academics, the smaller was the anxiety of intellectual theft $(F=25.58)$ and lack of familiarity with research interests of colleagues $(F=11.08)$. On the other hand, the older the age, the greater preference of individual work $(F=5.13)$ and the lack of familiarity with ICT $(\mathrm{F}=10.09)$. The higher the academic position, the greater lack of familiarity with ICT $(F=5.79)$. However, the higher academic position returned lower averages for barriers such as: anxiety of intellectual theft $(F=27.04)$, lack of comfortable places in academia for knowledge sharing $(F=18.76)$, lack of familiarity with research interests of colleagues $(F=18.68)$, lack of appropriate internet platform $(F=8.13)$ and lack of appropriate evaluation and remuneration system $(\mathrm{F}=30.14)$.

Table 9: Barriers to Knowledge Sharing

\begin{tabular}{l|r}
\hline \hline Barriers & Mean \\
\hline \hline Lack of time caused by workload & 3.80 \\
\hline \hline $\begin{array}{l}\text { Lack of remuneration system and academic employees' evaluation system } \\
\text { promoting knowledge sharing }\end{array}$ & 3.33 \\
\hline \hline Few specialists and experts in certain subject & 3.09 \\
\hline \hline Anxiety of intellectual theft & 2.87 \\
\hline \hline Preference for individual work & 2.80 \\
\hline \hline Lack of familiarity with research interests of colleagues from local academia & 2.75 \\
\hline \hline Lack of comfortable place in premises for meetings and scientific dialogues & 2.70 \\
\hline \hline Lack of internet platform or service coming up to academics' expectations & 2.37 \\
\hline \hline Lack of familiarity with ICT & 2.02 \\
\hline \hline
\end{tabular}

\section{Technologies and Tools Used in Knowledge Sharing}

The final findings are related to the technologies and tools used in knowledge sharing practices amongst Polish academics. Ten different ICT tools were identified (Table 10). In the light of the respondents' answers, the electronic mail was the most useful tool facilitating knowledge sharing, the only type that received a mean of more than 4.0. Other tools, especially personal web page or blog and social media had very little importance. It is worth adding that open access journals were relatively valuable in the knowledge sharing context. While these journals belong to formal scholarly communication channels rather than the informal channels which was the focus of this study, nevertheless, the list of electronic and online tools in the questionnaire would not be exhaustive without their inclusion.

Age and academic position variables were the most differential here. E-mail's importance increased with the respondents' age $(F=7.86, p<0.001)$. Regarding two tools: discussion forum and social media, a negative correlation was observed - the older the respondents and the higher their academic position are, the lower the assessment of usefulness of these tools (forums vs. age: $F=3.41, p=0.033$; social media vs. age: $F=13.87, p<0.001$, fora vs. status: 3.18, $p=0.041$; social media vs. status: $F=6.41, p<0.001$ ). The older the academics, the lower the importance of services dedicated to researchers ( $F=3.01, p=0.049)$. However, the older the academics and the higher their academic position, the higher assessment of the usefulness of preprints repositories and internal informatics system in home academia (preprints vs. age: $F=8.5, p<0.001$; internal system vs. age: $F=4.51, p=0.011$; preprints vs. status $F=19.62, p<0.001$, internal system vs. status: $F=5.6, p=0.003$ ). 
Table 10: Technologies and Tools Used in Knowledge Sharing

\begin{tabular}{l|r}
\hline \hline Technologies and tools used & Mean \\
\hline \hline E-mails & 4.25 \\
\hline \hline Open Access journals with Impact Factor & 3.33 \\
\hline \hline Open Access journals without Impact Factor & 2.54 \\
\hline \hline Internet services dedicated to researchers (e.g. ResearchGate, MendeleyWeb) & 2.28 \\
\hline \hline Preprints repositories & 2.26 \\
\hline \hline Open repositories for presentations, films etc. (e.g. Slideshare, Youtube) & 2.07 \\
\hline \hline Internet forums and discussion groups & 2.05 \\
\hline \hline Pnternal system used in home academia & 1.99 \\
\hline \hline Social media (e.g. Facebook, Twitter) & 1.89 \\
\hline
\end{tabular}

\section{DISCUSSION AND CONCLUSION}

This study concerned the phenomenon of knowledge sharing in the context of informal scholarly communication. Its results showed that on the one hand, the Polish academic community was convinced about the importance of such activity, especially as an occasion to broaden one's own knowledge, and on the other hand it treated it largely as a great pleasure. Nevertheless, this community created rather homogenous networks, generally limited to their own disciplines. It is worth adding, that these networks were not limited to the colleagues from the mother institution. Contrarily they were both international and trans-Poland in nature.

The favourite place to share knowledge and information between respondents is related to unofficial talks during conferences and seminars. However, conferences were also criticized, because of lecturers' concentration on their own presentations. The preferable form of knowledge sharing was face to face talks, despite the development of modern information and communication technologies. Unfortunately, the opinion of respondents about other academics in the context of sharing knowledge was not very positive: it was mildly positive, especially regarding the lack of orientation towards team work.

An interesting finding is related to motivators and barriers to sharing knowledge. The biggest barrier to sharing knowledge was the lack of time for free conversations, and the most important motivator could be the interest of colleagues. In other words, in the light of the conducted study, contemporary Polish academics were too busy to initiate scientific conversations because of the overload of other duties and the necessity to achieve more measurable effects required for promotion.

Regarding tools and technologies in knowledge and information sharing, it is noteworthy that Polish researchers commonly used only electronic mail and rarely other kinds of tools, such as personal web page, social media and blogs.

As assumed, the significant differences between subgroups of respondents as to their perception of various knowledge and information sharing issues were observed. They were related to gender, age, and the academic position of respondents.

The first national survey described in this article obtained in depth data on knowledge sharing behaviour of Polish academics. Findings may be valuable for every individual, who is 
engaged in such activity, as well as for managers of Polish academic institutions, who could be more responsible for enhancing such behaviours and maybe launch an appropriate reward system better connected with the real value of scientific conversation than the current parametric centred system (Reforms...2011). In the future, more detailed analyses are needed in the scope of knowledge sharing via informal scholarly communication: for example, regarding the influence of discipline or type of academia on this activity. Moreover, it would be very interesting to compare between nationalities and countries.

\section{ACKNOWLEDGEMENT}

The author is grateful to the national survey participants - all academic lectures and researches who filled out the questionnaire. This work was supported by the National Science Centre in Poland [grant number 2011/03/B/HS2/04436].

\section{REFERENCES}

Abrizah, A.; Hilmi, M.R. and Norliya, A.K. 2015. Resource-sharing through an interinstitutional repository motivations and resistance of library and information science scholars. The Electronic Library, Vol.33, no. 4: 730-748.

Abrizah, A.; Badawi, F. A.; Zoohorian-Fooladi, N.; Nicholas, D.; Jamali, H. R. and Norliya A.K. 2015. Trust and authority in the periphery of world scholarly communication: A Malaysian focus group study. Malaysian Journal of Library \& Information Science, Vol. 20, no. 2: 67-83.

Al-Hawamdeh, S. 2002. Knowledge management: re-thinking information management and facing the challenge of managing tacit knowledge. Information Research, Vol.8, no.1. Available at: http://InformationR.net/ir/8-1/paper143.html.

Bates, M.J. 2005. Information and knowledge: an evolutionary framework for information science. Information Research, Vol.10, no.4. Available at: http://InformationR.net/ir/104/paper239.html.

Bennet, D. and Bennet, A. 2008. Engaging tacit knowledge in support of organizational learning. VINE: The Journal of Information and Knowledge Management Systems, Vol.38, no.1: 72-94.

Brookes, B. 1980. The foundations of information science. Part1: Philosophical aspects. Journal of Information Science, Vol. 2: 125-133.

Cheng, M.Y.; Ho, J. S.Y. and Lau, P.M. 2009. Knowledge sharing in academic institutions: A study of Multimedia University Malaysia. Electronic Journal of Knowledge Management, Vol.7: 313-324.

Chong, C.W.; Yuen, Y.Y and Gan, G.C. 2014. Knowledge sharing of academic staff. A comparison between private and public universities in Malaysia. Library Review, Vol.63, no. 3: 203-223.

Day, R. E. 2005. Clearing up "implicit knowledge": implications for knowledge management, information science, psychology, and social epistemology. Journal of the American Society for Information Science and Technology, Vol.56, no. 6: 630-635.

de Solla Price, D.J. 1967. Communication in science. The ends-philosophy and forecast. In: A. de Reuck, J. Knight, eds. Ciba Foundation Symposium on Communication in Science. Documentation and Automation. London: J. \& A. Churchill Ltd.

Dokhtesmati, M. and Bousari, R.G. 2013. Knowledge sharing in Iranian academic institutions: meta analysis approach. Procedia. Social and Behavioral Sciences, Vol.73: 383-387. 
Farradane, J. 1980. Knowledge, information, and information science. Journal of Information Science, Vol. 2: 75-80.

Fernándes-Pérez, V.; Alonso-Galicia, P.E.; Fuentes-Fuentes, M.M. and Rodriguez-Ariza, L. 2014. Business social networks and academics' entrepreneurial intentions. Industrial management and Data Systems, Vol.114, No.2: 292-320.

Forkosh-Baruch, A. and Hershkovitz, A. 2012. A case study of Israeli higher-education institutes sharing scholarly information with the community via social networks. Internet and Higher Education, Vol.15: 58-68.

Fullwood, R.; Rowley, J. and Delbridge, R. 2013. Knowledge sharing amongst academics in UK universities. Journal of Knowledge Management, Vol.17, no.1: 123-136.

Hass, M.R. and Park, S. 2010. To share or not to share? Professional norms, reference groups, and information withholding among life scientists. Organization Science, Vol.21, no.4: 873-891.

Jashapara, A. 2005. The emerging discourse of knowledge management: a new dawn for information science research? Journal of Information Science, Vol.31, no.2: 136-148.

Kim, S. and Ju, B. 2008. An analysis of faculty perceptions: attitudes toward knowledge sharing and collaboration in an academic institution. Library and Information Science Research, Vol.30: 282-290.

Lauring, J. and Selmer, J. 2012. Knowledge sharing in diverse organisations. Human Resource Management Journal, Vol.22, no. 1: 89-105.

List of areas of academic study, academic disciplines and fields of study in the arts and sciences. 2006. Ministry of Science and Higher Education. Republic of Poland. Available at:http://www.nauka.gov.pl/g2/oryginal/2013_05/9e30526898a1faea585252c810472 7c8.pdf.

Luzón, M.J. 2009. Scholarly hyperwriting: the function of links in academic weblogs. Journal of the American Society for Information Science and Technology, Vol.60, no.1: 75-89.

Nonaka, I. and Takeuchi, H. 1995. The knowledge-creating company. How Japanese companies create the dynamics of innovation. New York: Oxford University Press.

Nordin, N.A.; Daud, N. and Osman, W.U.K.M. 2012. Knowledge sharing behaviour among academic staff at a public higher education institution in Malaysia. International Journal of Social, Management, Economics and Business Engineering, Vol. 6: 696-701.

Padilla-Meléndez, A. and Garrido-Moreno, A. 2012. Open innovation in universities: what motivates researchers to engage in knowledge transfer exchanges. International Journal of Entrepreneurial Behaviour \& Research, Vol.18, no.4: 417-439.

Pikas, C.K. 2006. The impact of information and communication technologies on informal scholarly scientific communication: a literature review. Doctoral Seminar in Information Studies, University of Maryland College of Information Studies. Available at: http://terpconnect.umd.edu/ cpikas/878/Pikas_The_Impact_of_ICTs_on_ISSC_0506.p df.

Pilerot, O. 2013. A practice theoretical exploration of information sharing and trust in a dispersed community of design scholars. Information Research, Vol.18, no.4. Available at: http://InformationR.net/ir/18-4/paper595.html.

Pilerot, O. and Limberg, L. 2011. Information sharing as a means to reach collective understanding: a study of design scholars' information practices. Journal of Documentation, Vol.67, no.2: 312-333.

Polanyi, M. 1958. Personal knowledge: towards a post-critical philosophy. London: Routledge.

Ramayah, T., Yeap, J.J. and Ignatius, J. 2013. An empirical inquiry on knowledge sharing among academicians in higher learning institutions. Minerva, Vol.51: 131-154. 
Reforms of research and higher education systems in Poland. 2011. Ministry of Science and Higher Education. Available at: http://www.nauka.gov.pl/en/ reforms-of-research-andhigher-education-in-poland/.

Sohail, M. S. and Daud, S. 2009. Knowledge sharing in higher education institutions: Perspectives from Malaysia. The Journal of Information and Knowledge Management Systems, Vol.39, no. 2: 125-142.

Świgoń, M. 2012. Zarzqdzanie wiedzq i informacjq. Podstawy teoretyczne. Badania w wymiarze indywidualnym. [Knowledge and information management. Theoretical basis. Studies at an individual level]. Olsztyn: Wydawnictwo Uniwersytetu WarmińskoMazurskiego w Olsztynie.

Świgoń, M. 2013. Personal Knowledge and Information Management - conception and exemplification. Journal of Information Science, Vol.39, no.6: 832-845.

Świgoń, M. 2015a. Dzielenie się wiedzq i informacjq. Specyfika nieformalnej komunikacji w polskim środowisku akademickim. [Knowledge and information sharing. Characteristics of Polish informal scholarly communication]. Olsztyn: Wydawnictwo Uniwersytetu Warmińsko-Mazurskiego w Olsztynie.

Świgoń, M. 2015b. Knowledge and information sharing in the opinion of the Polish academic community. World Academy of Science, Engineering and Technology. International Journal of Social, Behavioral, Educational, Economic and Management Engineering, Vol.9, no.4.

Tenopir, C.; Levine, K.; Allard, S.; Christian, L.; Volentine, R.; Boehm, R.; Nichols, F.; Nicholas, D.; Jamali, H.R.; Herman, E. and Watkinson, A. 2016. Trustworthiness and Authority of Scholarly Information in a Digital Age: Results of an International Questionnaire. Journal of the Association for Information Science and technology, Vol.67, no.10: 2344-2361.

Wang, C.C. and Yang, Y.J. 2007. Personality and intention to share knowledge: an empirical study of scientists in an R\&D laboratory. Social Behavior and Personality, Vol.35, no.10: 1427-1436.

Xiao, L. and Askin, N. 2014. Academic opinions of Wikipedia and open access publishing. Online Information Review, Vol.38, no.3: 332-347. 